\title{
Géza Kállay
}

\section{"It is not so, nor "twas not so"}

\section{Funny words and the role-playing of 'double-tongues' in Much Ado About Nothing}

\begin{abstract}
This paper examines one of Benedick's remarks in the play: "Like the old tale, my lord: 'It is not so, nor 'twas not so: but indeed, God forbid it should be so!' " This quotation is from "an old tale," first identified in 1821 by a certain Mr Blakeway for the old Variorum edition of Much Ado. Drawing especially on the Oxford English Dictionary, I first examine the semantic and the grammatical nature of "It is not so, nor 'twas not so"; then, relying on Paul Ricoeur's The Rule of Metaphor and Stanley Cavell's The Claim of Reason, I argue that reality, just like fiction, is always created in an attitude, in a mode of approaching what is before us; we are only given the so, never the is. Thus, whether what we, within the so, are encountering is 'real' or 'imaginary' will not depend on the amount of certainty we have with respect to the approached object; the object will always be in the mode of is and is not at the same time. Within so, we construct both reality and the imaginary rather through 'it is not not so' than through either just 'is,' or just 'is not.' The difference in our respective attitudes might be that with respect to the imaginary we have a greater awareness of the ever-presence of not in is, or rather of the not not: we do not have a greater or lesser amount of certainty of, but a greater amount of intimacy with, the not not.
\end{abstract}

The phrase "funny words" - like puns Elizabethans and Jacobeans were so much fond of - is in itself ambiguous: it may refer to surprising expressions which make us laugh, to double entendres, to innuendoes, to in-vogue vagueness and to speechified specificity, to phonetic or semantic equivocality or univocality, and to so much more. From the linguistic point of view - and, for that matter, from interpretative, and "analytical" aspects - Much Ado About Nothing seems to be one of the least controversial plays in the canon, although, as it will become clearer below, this is not necessarily so because of its widely accepted, indisputable merits. However, right now let us keep the linguistic perspective in mind:

The AnaChronisT (2003) 29-45 ISSN 1219-2589 
those who tend to treat Shakespeare's language play by play - such as Ifor Evans ${ }^{1}$ or Frank Kermode ${ }^{2}$ - emphasise that "it is in liveliness and quickness that much that is most attractive in the language of the play is to be found" 3 and that "the main of the play lies in the wit combats ... and they are not always successful." 4 For those who approach Shakespeare's language from the point of view of grammatical or semantic categories, rhetorical figures, etc. - such as N. F. Blake, ${ }^{5}$ Hilda M. Hulme ${ }^{6}$ or S. S. Hussey ${ }^{7}$ - this comedy (compared, for example, to Troilus and Cressida, or to The Winter's Tale) does not seem to be of particular interest; Blake largely quotes it to illustrate the use of the subjunctive, ${ }^{8}$ Hulme provides some brilliant readings of a few puns, ${ }^{9}$ and Hussey points out those features of the play for which it is, in most commentaries, acclaimed: Dogberry's malapropisms and the frequent use of euphuism. ${ }^{10}$ Evans and Kermode also remind us of the unusual proportion between prose and blank verse ${ }^{11}$ (42 percent to 58), ${ }^{12}$ yet Evans also notes the remarkable lack of references to language itself in the play: "The only comment on language," he says,

is made by Benedick, where he speaks of the change of Claudio, once he is in love: "He was wont to speak plain and to the purpose, like an honest man and a soldier, and now is he turned orthography - his words are a very fantastical banquet, just so many strange dishes" (II.iii.18-21). ${ }^{13}$

Yet there is an even earlier instance when Benedick wishes to sketch out the landscape of enamoured Claudio's state of mind (or his “five wits," in the sense

1. Ifor Evans, The Language of Shakespeare's Plays (London: Methuen, 1959 [1952]).

2. Frank Kermode, Shakespeare's Language (London: Allen Lane, The Penguin Press, 2000).

3. Evans, p. 111.

4. Kermode, p. 77.

5. N. F. Blake, The Language of Shakespeare (London: Macmillan, 1989 [1983]).

6. Hilda M. Hulme, Explorations in Shakespeare's Language (London: Longman, 1962).

7. S. S. Hussey, The Literary Language of Shakespeare (London and New York: Longman, $1992[1982])$.

8. Blake, p. 126 and p. 8.

9. Cf. Hulme, p. 173, concerning a pun Borachio and Conrade produce, or see pp. 284-285, where she explores the puns turning on the word base.

10. Hussey, p. 28 and pp. 75-76; see also Evans, p. 108.

11. Cf. Evans, p. 108.

12. Kermode, p. 48.

13. All textual references are to the Arden edition of Much Ado, ed. A. R. Humphreys (London and New York: Methuen, 1985 [1981]). Below, I will refer to this edition as Humphreys. 
of 'common wit, imagination, fantasy,' cf. I.i.6o). After Benedick, without further ado, lets Don Pedro know that Claudio is in love "with Hero, Leonato's short daughter" (I.i.198), Claudio retorts with a conditional: "If this were so, so were it uttered" (I.i.199), to which, in turn, Benedick responds with: "Like the old tale, my lord: 'It is not so, nor 'twas not so: but indeed, God forbid it should be so!'” (I.i.200). Whereas in the passage Evans quotes Claudio goes through a kind of metamorphosis (he becomes orthography, i.e. 'over polished style' ${ }^{14}$ ) and his changing attitude to language is described in terms of food metaphors, the language characterising his attitude to the newly met Hero is a quotation, a guest text in the play, indicating that Claudio is not only wavering between 'two realities' but that he fears one of the alternatives coming true as well: "God forbid it should be so!" The matter - at least in the first approximation - could easily be settled by the following note: 'Benedick wants to tell Don Pedro that his friend, Claudio, has fallen in love with Hero, yet Claudio - especially because of the novelty of his feelings - is still in two minds about his emotions; he does desire them, yet at the same time he would like to deny them, too.'

However - as I will argue below - Benedick's quote perhaps deserves some more attention. As he himself, and all editions, note, 'It is not so, etc.' is from "an old tale," first identified, it seems, in 1821 by a certain Mr Blakeway for the old Variorum edition of Much Ado. ${ }^{15}$ As usual, the tale - as A. R. Humphreys tells us in the fifth appendix of the Arden edition ${ }^{16}$ - exists in several versions (the most well-known is the Robber Bridegroom one, of which the Bluebeard story is a variant), yet in the version Mr Blakeway knew, the first two clauses, "It is not so, nor it was not so," are introduced by the heroine of the story, Lady Mary, who is hopelessly wooed by a certain Mr Fox - the name surely secures a place for the story also among the bestiaries in the Mediaeval Reynard the Fox tradition (cf. Volpone ${ }^{17}$ ).

In the story Mr Blakeway recounted, Lady Mary is down in a country seat with her two brothers and a cheerful company - very similar to the one we find in Much Ado - gather around them. They are eating and drinking, they are tell-

14. Humphreys, p. 132.

15. See for example the Arden edition of the play from 1917, ed. J. C. Smith (Boston, London, etc.: D. C. Heath and Company, 1917), pp. 80-81.

16. Humphreys, pp. 232-233.

17. Ben Jonson, Volpone, or The Fox, Epicene, or The Silent Woman, The Alchemist, Bartholomew Fair, ed. Gordon Campbell, Oxford Drama Library (Oxford: Clarendon Press, 1995), pp. xiii-xiv. 
ing fantastic stories to one another but Mr Fox would like to see Lady Mary privately as well and invites her to his house. One day the lady decides to accept the invitation but in Mr Fox's house she finds the most horrible things: tubs of blood, skeletons, dismembered female bodies, etc. Yet also an inscription above every door: "Be bold, be bold, but not too bold," which is appended above the last door by "lest that your heart's blood should run cold." This is the first "refrain" of the story, which - like It is not so. . . - has a kind of modal value as well, in characteristically recommending, or even prescribing, a certain attitude or state of mind, or even a kind of expectation the heroine should have with respect to the 'piece of reality' she is going to encounter. We can only infer that Lady Mary "was," indeed, "not too bold" because she does not have much time to think: $\mathrm{Mr}$ Fox is approaching the house with a young lady-victim and Lady Mary has "just time to slip down, and hide herself under the stairs." ${ }^{18}$ As Mr Fox is dragging the unfortunate young woman up the stairs by the hair, she tries to catch hold of the banister with her hand, on which there is a rich bracelet, yet this hand lands in Lady Mary's lap because Mr Fox mercilessly cuts it off. ${ }^{19}$ Lady Mary manages to get back to her brothers' house safe and sound, and it is obscure whether she relates them the horrors or not because we next see her amid the large company again, amusing "each other with extraordinary anecdotes" ${ }^{20}$ and Mr Fox is also present, as if nothing had happened. It is then that Lady Mary

at length said, she would relate to them a remarkable dream she had lately had. I dreamt, ${ }^{21}$ she said, that you, Mr. Fox, had often invited me to your house. I knocked, etc., but no one answered. When I opened the door, over the wall was written, 'Be bold, be bold, but not too bold.' But, said she, turning to Mr. Fox, and smiling, It is not so, nor it was not so; then she

18. Humphreys, p. 233.

19. The hand with a bracelet, or a finger with a ring, in which psychoanalysts would surely see either the symbol of violated chastity, or, because of its further function, even an (inverted) castration-complex, is a recurring element in all the variants of the story, for example in the Grimm-version (The Robber-Bridegroom); or see Webster's The Duchess of Malfi, where, again as an "inverse" of our story, two brothers torture their sister and the younger brother, Ferdinand, nourishing an incestuous passion for the Duchess, in Act 4 Scene 1 presents her with a ring "on a dead man's [Antonio's, her husband's] hand . . . for a love-token" (John Webster, The Duchess of Malfi and Other Plays, Oxford English Drama, ed. René Weis [Oxford: Oxford University Press, 1996], IV.i.43 and 46).

20. Humphreys, p. 233.

21. That the 'robber-bridegroom' has to face 'reality' disguised as a dream is, again, a recurring topos of the tale, see again the Grimm version for example. 
pursues the rest of the story, concluding at every turn with It is not so, nor it was not so, till she comes to the room full of dead bodies, when Mr. Fox took up the burden of the tale, and said, It is not so, nor it was not so, and God forbid that it should be so: which he continues to repeat at every subsequent turn of the dreadful story, till she came to the circumstance of his cutting off the young lady's hand, when, upon his saying as usual, It is not so, nor it was not so, and God forbid it should be so, Lady Mary retorts, But it is so, and it was so, and here the hand [sic!] I have to show, at the same time producing the hand and bracelet from her lap: whereupon the guests drew their swords, and instantly cut Mr. Fox into a thousand pieces. ${ }^{22}$

Benedick's quote ("Like the old tale, my lord. . .) is triggered by - as we saw - a conditional coming from Claudio "If this [i.e. his being in love with Hero] were so, so were it uttered" (I.i.199), meaning, it seems, that 'if Claudio's state of mind, as a piece of "reality," really contained the content that he is in love with Hero, then Benedick's words would be the appropriate ones to describe this state of mind.' Thus, Benedick's plain, straightforward statements, uttered - and quoted - earlier: "he [Claudio] is in love. With who? ... Mark how short his answer is: with Hero, Leonato's short daughter" (I.i.195-198) are given a kind of hypothetical, or even retentive truth value; Benedick's words are true if and only if they describe Claudio's 'five senses' accurately. Therefore, from Claudio's tentative phrases we might infer that the usual, familiar order of representation is upset: it is not so that there is an emotion one feels and then calls it by a name; rather it is so that there is a description which might help a feeling to come into being (or, perhaps more accurately, language and reality are born in the same moment). It is also noteworthy that Benedick quotes Mr Fox, the trap-maker, rather than Lady Mary: he uses the longer version appended by "God forbid it should be so."

That reality (this time a piece of mind with Claudio as its sole authority) is playing hide-and-seek with language might be just as unsurprising and negligible as Benedick's reference to Mr Fox, if Much Ado were not a comedy in which much is at stake as regards words and belief. Much depends on whether words can adequately describe what is and what is not, what was and what was not, so. At the beginning of the play, Beatrice charges Claudio with having "caught the Benedick" (I.i.81), as if her future bridegroom were a disease; now in the play

22. Humphreys, p. 233. 
belief is like a disease, and most of it is contagious and false. If the interpreter of the play thinks that Beatrice and Benedick fall in love only at the end of Much Ado, then it may be claimed that words are able to create a reality and then 'real reality' catches up with it; if one believes that 'in fact' they are in love from the start, then language is 'lagging behind' reality and is, after all, nothing but fireworks - most of it is even superfluous. But there is the more 'serious case,' the case of the "falsely accused woman," testifying to what, ironically, it is precisely Hero's lot to formulate. Hero, in the deception scene she plays with Ursula, half-mockingly says: "one doth not know / How much an ill word may empoison liking" (III.i.85-86). At the beginning of the play there is peace, since the war is over, so instead of swords, tongues and even "double tongues" may fight (cf. Don Pedro's: “there's a double tongue, there's two tongues," V.i.166167). Yet tongues are also acknowledged as dangerous weapons which can kill: Hero 'dies' and gets 'resurrected' in the course of the comedy (like Hermione in The Winter's Tale) but if there were no Friar trusting her innocence, if there were no Beatrice being convinced that this is just a misunderstanding, and if there were no Benedick ready to challenge Claudio to a duel (to prove his love and manliness to Beatrice as well), the epitaph Claudio reads out for Hero's tomb would become permanent. Love moves in the dangerous presence of death all the time, as Leonato's strange, almost Lear-like outburst ("Could she here deny / The story that is printed in her blood? / Do not live, Hero, do not ope thine eyes," IV.i.121-123) also indicates. Language can create and destroy at the same time, and some of it must be erased with, of course, language again. It is hard to deny that the play raises questions like: does love need acknowledgement in words, or is it enough if one "just loves?" - a question which might again recall King Lear. If language is nothing but a social construct, then can love - a necessary but not necessarily sufficient condition for marriage - and marriage be considered to be solely - or at least largely - social fabrications? ${ }^{23}$ Or: "God

23. As, for example, Stephen Greenblatt argues in the "Introduction" to Much Ado in the Norton Shakespeare (The Norton Shakespeare, gen. ed. Stephen Greenblatt, with Walter Cohen, Jean E. Howard and Katharine Eisaman Maus [New York and London: W. W. Norton and Company, 1997], pp. 1381-1387, especially p. 1386). Below, I will refer to this edition as the Norton Shakespeare. Or see Adam Piette's wonderful recent study on the role of split subjects in the play, in which he remarks: "The dangerous corollary of the [orchard] scene is that love is fabricated by social scenes, and the way one lives out one's self is conditioned by team performances of ideal and satirical role versions of one's supposed interiority" (Adam Piette, "Performance, Subjectivity and Slander in Hamlet and Much Ado About Nothing," in 
forbid that it should be so"? Is there anything outside (besides, above, behind) language? If nothing is, is it worth much ado? What is the relationship between what one can say and what one can see (note)? Can one mean what one can see?

It is in line with the above questions that I would like to deal with what the "very fantastical banquet," Benedick's "funny words" recalling the "old tale" might treat us to. First, I will try to examine the semantic and the grammatical nature of "It is not so, nor 'twas not so"; then I will try to argue that the sentence could not only be treated as a kind of motto to the play, but, in a certain way, as the display of an attitude one might have to the fictitious, to the product of imagination in a wider sense, and finally, and as a corollary of this section, I will return to the vexed question of the relationship between representation by language, and reality.

What does "It is not so, nor 'twas not so" mean? Of course, it is the double negation in the second clause ("nor 'twas not so") which is of particular interest. Yet perhaps what we are encountering here is nothing extraordinary; as several dictionaries and grammars on early modern English testify, a negative following nor in Shakespeare's time is still quite common; in the Oxford English Dictionary we find the following examples for "nor followed by another negative": "I may not eate your benys . . . nor I may not drink your thyn ale." The text is from 1440 , and it is also remarkable that nor does not bring about the inversion of the modal auxiliary and the subject, which is the standard operation in modern English (instead of nor may I we read: nor I may), as there is no inversion in Benedick's quote, either; we have "nor 'twas [it was] not so" (instead of nor was it not so). In the example from 1440, the double negation (the standard procedure, by the way, in modern Hungarian, too) is just to emphasise that the speaking persona thinks he should neither eat the other's "benys" (beans?), nor drink his or her ale, so the purport is that he is adamant on not drinking. A similar example is from 1568, from Grafton's Chronicle: "No man was called to answere, nor no question put unto any person by the sayd enquest." A third example is from 1598, the year in which Much Ado was most probably written: "He could lay no iust cause against him, nor openly durst not command the murdering of his brother." Here the meaning is quite straightforward (and quite natural to a Hungarian ear): 'he could not charge his brother with anything, nor did he dare to order his assassination openly.' Finally, here is a quote from Henry V (and many

Early Modern Literary Studies, 7.2 [September 2001], 4.1-29, p. 15; <http//purl.oclc.org/ emls/07-2/pietslan.htm>.) 
other examples can be found): King Charles tells Harry that "[n]or this [i.e. that in signed documents Charles will call him 'King of England and heir to France'] I have not, brother, so denied / But your request shall make me let it pass" (V.ii.115-116). ${ }^{24}$

Thus, Lady Mary, relating the truth she experienced in Mr Fox's house, yet disguising it as a dream, might not be saying more than: 'all that I am telling to you now is not so (not true), and it was not so (not true) when I dreamt it (or: because I dreamt it), either.' Applied by Benedick to Claudio, the sentence might mean, roughly: 'It is not so that he is in love, and it is not the case that he was in love when he talked to me about Hero, either,' or, more simply: 'he is not in love, nor was he in love when we talked a moment ago.' So the double negation, both in Lady Mary's and in Benedick's respective locutions might not serve any other purpose than to emphasise the continuity between past and present: it is not so that this or that was the case but by now it has changed, but this is what has always been the case. Not surprisingly, all this can be taken as plain, straightforward irony: both Lady Mary and Benedick are implying that the exact opposite of what they are saying has been the case all the time: Mr Fox is a lady-killer and Claudio is in love.

Yet the Oxford English Dictionary knows of another sense of nor (listed as the fifth meaning of the word) when nor means 'and not.' It is true that this sense might usually be read into nor when the first clause is an affirmative one, as in the following example from 1523: "I greatly desyre to see the kynge my master, nor I will lye but one nyght in a place, tyll I com there," where the following paraphrase could be constructed: 'I greatly desire to see the king, my master, and I will not sleep more than one night somewhere before I get there.' Thus here nor is nothing but emphatic not; however, as both the Oxford and the Webster Dictionaries note, it may also be used "in continuative narration, with the force of neither or and not" (Oxford), and Webster, giving a very similar definition, ${ }^{25}$ provides the following example: "They are happy, nor need we worry," where perhaps the following paraphrase is in place: 'They are happy, and we need not worry, either.' Now if we accept that the 'and not' meaning of nor is not a totally implausible interpretation of the conjunction in "It is not so, nor 'twas not so," then we might come up with the following reading: 'It is not so, and it was not not so, either,' where the double negation in the second clause

24. The quotation is according to the Norton Shakespeare.

25. "[U]sed after an affirmative clause or as a continuative in the sense of and not. .." 
only logically implies an affirmative: it was so. Rhetorically, there is a very significant difference between saying: it is (was) so and it is (was) not not so. First I will try to show what we gain if we support that this reading might also colour the meaning of the sentence, and then I will return to the difference between the simple affirmative and the affirmative through double negation.

I take my first clue from the fact that the sentence occurs in a tale and that it involves the existence and non-existence of a certain state of affairs through the copula be in its relatively rare 'existential' meaning, supplemented by the adverbial so, the latter standing for a whole clause or sentence. Now in fairy tales, existence is usually clarified as early as its very beginning, with the help of the pronoun there as subject + copulative be as subject-complement, be meaning 'exist': "Once upon a time there was a young lady, called Mary. .." Yet - and here comes my second clue - Paul Ricoeur, in The Rule of Metaphor, quotes (in the chapter "Metaphor and Reference") Roman Jakobson's “Two Aspects of Language and Two Types of Aphasia Disorders":

The supremacy of poetic function over referential function does not obliterate the reference but makes it ambiguous. The double-sensed message finds correspondence in a split addresser, in a split addressee, and what is more in a split reference, as is cogently exposed in the preambles to fairy tales of various peoples, for instance in the usual exordium of the Majorca storytellers: "Aixo era y no era" (It was and it was not). ${ }^{26}$

I just note in passing that among the "various peoples" Jakobson refers to there are also the Hungarians, who often start their fairy-tales very similarly to the storytellers in Majorca: "Hol volt, hol nem volt (volt egyszer egy leány)," a literal translation of which could be: 'Where was, where was not (there was once a girl)' - perhaps my fascination with Benedick's (and Lady Mary's and Mr Fox's) “It is not so, nor 'twas not so" has to do with this fact, as a part of my linguistic competence, as well.

But let us proceed with Ricoeur, who builds a substantial portion of his theory of metaphor on "Aixo era y no era," using it as a kind of motto. As a comment on Jakobson, Ricoeur says: "Let us keep this notion split reference in mind, as well as the wonderful 'It was and was not,' which contains in nuce all that can be

26. Paul Ricoeur, The Rule of Metaphor: Multi-disciplinary Studies of the Creation of Meaning in Language, trans. Robert Czerny, with Kathleen McLaughlin and John Costello, SJ (Toronto: University of Toronto Press, 1979 [1977]), p. 224. 
said about metaphorical truth.” ${ }^{27}$ Ricoeur, who argues for a referential conception of poetic language, ${ }^{28}$ claims that while in metaphor a new semantic pertinence, a semantic innovation emerges out of the "ruins" of the literal meaning, the "metaphorical interpretation also sustains a new referential design, through those same means of abolition of the reference corresponding to the literal interpretation of the statement." ${ }^{29}$ Drawing also on Wittgenstein, Marcus B. Hester, and Nelson Goodman, Ricoeur tries to convince us that the proximity of the (ruined) literal meaning and the (new) metaphorical one - the 'content' of this proximity given in the resemblance between the two meanings - establishes a proximity between the references (the 'things' the two respective meanings denote) themselves. The 'new thing,' the reference of the metaphorical meaning can be caught sight of only through a "new vision," 30 which is metaphorical itself: it is metaphorical 'seeing as.' Yet as implies more than the simple reorganisation of reality; what comes within the scope, the range, the efficacy of as, is the manifestation of "a way of being of things," in which 'mode of being,' a 'being so' corresponds to the semantic innovation in language. ${ }^{31}$ And for Ricoeur as "must be treated as a metaphorical modality of the copula itself"; as operates alongside the copula, as "is not just the comparative term among all the terms, but it is included in the verb to be, whose force it alters." $3^{2}$ Consequently, in metaphor operating with the verb be (e.g. she is a rose), 33 the subject (she) is seen as a rose, yet it is not only the relational function of is (be, the copula) which is affected by the metaphorical process but its existential sense as well. ${ }^{4}$ she is 'recreated' as a rose, she arrives at a new being in being seen as a rose, yet the tension between the subject and predicate (so often noted by theories of metaphor) is retained also in terms of the fact that she is, at the same time, not a rose. For Ricoeur, if I understand him correctly, the 'is not' part of is is not only implied in the impossibility of the literal interpretation of the sentence, in the claim that the literal meaning is ruined so that the innovative, new semantic pertin-

27. Ricoeur, p. 224.

28. Cf. Ricoeur, p. 230.

29. Ricoeur, p. 230.

30. Ricoeur, p. 230.

31. Cf. Ricoeur, p. 239.

32. Ricoeur, p. 248.

33. Ricoeur does not use this example here but this sentence is among the standard illustrations for metaphor.

34. Cf. Ricoeur, p. 248. 
ence might prevail, but is not is present in the newly created reference of the metaphorical meaning as well. In other words, the new creation: 'she-(seen)-asa-rose,' has a 'dual' status: she, a woman, is not only no longer just a woman but a rose as well, but she is not totally a rose, either. Yet she is not totally a rose not only in the sense that 'something of the woman still remained in her' but also in the sense that there is a resistance in the referential function of rose, which prevents it from totally turning into a woman. Somebody being a rose, it seems, is not a simple denial of the previous mode of existence for either of the two parties (she and rose) involved; through the created resemblance - established through is - between the woman and the rose, the former way of being is rather accompanied, or complemented by, the new one, and the newly created referent will be a "split" one: a woman who is and is not a rose at the same time. 35

Neither doing full justice to Ricoeur's refined theory, nor to the notions of "split addresser and addressee" introduced by Jakobson, I will concentrate on "split reference" in the above sense. Now Ricoeur's fascination with "It is/was and it is/was not," illustrating here the way (subject-predicate) metaphors operate, might be extended to express an attitude, a state of mind we may have to the fictitious, to the verbally invented, to the product of the imagination. Or I should perhaps rather say that "Aixo era y no era" is a 'royal road' to reconstruct the way the imaginary is constructed, yet it seems to me that - especially through embedding one fiction into another - there are more than one splits in the references. Let me explain this.

In the story Mr Blakeway recounts, there is a heroine, who relates a story, yet what she tells is, within the fiction of the whole story, true in the sense that she tells what is retained in her memory, in 'ideas,' and 'impressions,' from the horrors she actually went through and saw with her own eyes, heard with her own ears, etc. But she, in order not to frighten Mr Fox away right at the beginning, in order to create a 'narrative space' for her story, to be able to tell, from the beginning to the end, what she experienced, disguises the true story as a dream; she pretends that her mind contains nothing more than a special kind of

35. It could be claimed - and this has always been a controversial part of the theory of metaphor - that the rose 'is and is not a rose,' either, yet the grammatical structure of a metaphorical expression (this time what is in the subject and what in the predicate position) cannot be neglected, since it seems that there is no absolute (or complete) symmetry between the two positions; although it would be hard to deny that the word (phrase, etc.) which plays the role of the predicate is affected by the subject-word as well, the subject will always be 'more in focus.' Yet this problem cannot be pursued any further here. 
fiction. Ignoring here the hopelessly vast literature on dreams, I only single out two features of theirs. First, a dream is a special type of fiction because we are and are not the authors of it; apart from day-dreaming, I cannot make myself dream something, at the same time I cannot avoid my dreams; once I have one, I have to watch it, from the beginning to the end, and after waking up I know that I saw it in a movie of which I was the single spectator; there is no other authority for it than me. Therefore only I (my mind, my previous impressions, repressions, my attitude to people, to things, etc.) can be responsible for it. Yet when I want to share my dream, to make it 'social,' I - and this is the second feature I wish to emphasise - cannot but use language; the dream I tell is, strictly speaking, not my dream but a report of it, verbalised and transformed into a narrative, which might be fragmented, discontinuous, chaotic, yet, precisely for the sake of being understood, it must strive towards some kind of coherence, imposed on it by the interpretative process. ${ }^{36}$ So what lends a fictive aura to Lady Mary's narrative within the narrative is that a dream is and is not one's invention, that it is and is not what was actually dreamt. But these is's and is not's are further split by the (within-the-story) fact that what she relates is not a dream and the 'reality' that reaches out, like a hand, from the dream into the 'reality' of the whole tale is precisely the hand, the hand with a bracelet that had been cut off and can now be produced as evidence. It is the unfortunate young woman's hand which erases the 'fiction' and 'awakens' everyone to 'reality,' it is the hand which wipes off the optative-volitional subjunctive with which Mr Fox joins in the narrative as if he were trying to find out the 'truth' together with Lady Mary: "God forbid it should be so," it is the disclosure of the hand which changes so to show: "upon his saying as usual, It is not so, nor it was not so, and God forbid it should be so, Lady

36. Cf. "To begin, there [in psychoanalysis] enters into the field of investigation and treatment only that part of experience which is capable of being said. ... This screening through speech in the analytic situation also functions as a criterion for what will be held to be the object of this science: not instinct as a physiological phenomenon, not even desire as energy, but desire as meaning capable of being deciphered, translated, and interpreted. ... We can already see the misunderstanding that prevails in ordinary epistemological discussions: facts in psychoanalysis are in no way facts of observable behaviour. They are 'reports.' We know dreams only as told upon awakening, and even symptoms, although they are partially observable, enter into the field of analysis only in relation to other factors verbalized in the 'report' " (Paul Ricoeur, "The Question of Proof in Freud's Psychoanalytic Writing," in The Philosophy of Paul Ricoeur: An Anthology of His Work, ed. Charles E. Reagan and David Stewart [Boston: Beacon Press, 1978], pp. 185-186). 
Mary retorts, But it is so, and it was so, and here is the hand I have to show," the so-show pair serving as a verbal index to the dramatic turn. Even further, as we can see from "But it is so, and it was so," uttered together with the exposure of the hand, the enigmatic double negation in "nor 'twas not so" is, retrospectively, disambiguated: since the "positive" counterpart of the negative "it is not" and "nor 'twas not" is "it is" and "it was," respectively, we may now conclude with certainty that nor was nothing but 'just' a 'standard' emphatic no(t). However, on the strictly verbal level, nor and not are there and they are there together; Lady Mary could have said: "It is not so, and it was not so" but she chose the more complex double negative, creating, very much in line with the nature of dreams and fairy-tales, at least some uncertainty around what is and was so, and what is not and was not so. So even if the 'and not' reading of nor is not colouring the standard reading of the conjunction, "nor-not" does become, through the hide-and-seek 'reality' plays with 'fiction,' a verbal index of a constant splitting and re-splitting of re-ferences. 'It was so-it was not so-it is so-it is not so,' yet my main point, drawing on Ricoeur, is that copulative-existential be and not do not simply create a positive-negative pair; what offers itself here to describe our attitude to the fictitious is an 'is not not so,' which is a statement, logically yielding is, yet, rhetorically, the double negation heavily curtails the absolute triumph of the positive, and the second not, its intrusive, or even obtrusive presence is pertinent or even impertinent because it accentuates the 'is not' inhering, always already, in every is in fiction or in metaphor. Thus it seems that one way to describe our relation to the imaginary, or rather to reconstruct our way of creating it is to say that, instead of straightforward is or is not we need a 'third' category, where is restricts the scope of, and suspends the power of not just as much as not compromises and withholds is. Benedick's outburst in Act II Scene i, after the first dance-and-mask scene, is equally telling: "But that my Lady Beatrice should know me, and not know me!" (189-190). The positive and the negative are in operation at the same time; yet if we return to Benedick's quote "Like the old tale, my lord. .." we are immediately reminded that "It is not so, nor 'twas not so" is not only appropriated, i.e. applied to Claudio here, but it is embedded, as a further twist, or split, in the fiction of the play as well. Now we could raise the issue of how the vision of the spectator or reader of the play, conscious, always already, that he or she is watching a play, a piece of fiction, is guided by the visions of the various characters, such as Claudio, or Benedick, how that is further complicated by the spectator's awareness of the flesh-and-blood 'reality' of the 
actors (as real, human beings) personifying Claudio, or Benedick, how this awareness is further split by the post-modern notion of the subject as "the originally divided, split subject of desire, the profoundly subjected subject, reduced to only the desire for that part of itself that language simultaneously arouses and forbids it from rejoining," 37 and how Shakespeare participates in this 'deconstruction,' staging his "cultural nightmare, which could be expressed by this question: what is to distinguish selves fabricated by social performance of interiority from the secret roles being performed by the vicious and slanderous forces in our culture?" ${ }^{38}$ The relationships might be so complicated that perhaps all the factors could not even be expressed in human language: they are rather to be seen, shown, as the cut-off hand; so can only be given substance by show.

But is that really so? First, it could easily be claimed that not only in any of Shakespeare's plays but also in any art-work of significance (whatever that means) the destabilisation of reference, the dismantling of straightforward meaning, the displacement of signifier with respect to the signified take place all the time, together with the work of art in question reflecting, and further reflecting (re-reflecting) on these problematisations. Why I think Much Ado deserves special attention is precisely because of the light treatment it usually receives; as David Lucking rightfully observes, the play is "too easily dismissed," even by serious scholars, "as a mere bagatelle unworthy of serious consideration." 39 Another way of putting this is that Much Ado About Nothing lives up to its title. ${ }^{40}$ Yet, as Lucking further argues, the problem I called at the beginning of this study the problem of representation and our attitude to fiction and reality "is radicalised [in the play] by reducing the sign to a mere cipher": ${ }^{41}$ we might as well take nothing seriously and treat it - as generations of philosophers, from Parmenides to Heidegger, have done - as an exciting enquiry into the "nonevent or aporia ... as the centre of significance in the play," ${ }^{2}$ or, I would ven-

37. Mikkel Borch-Jacobsen's words in "The Freudian Subject, form Politics to Ethics," quoted by Piette, p. 1 .

38. Piette, p. 29.

39. David Lucking, "Bringing Deformed Forth: Engendering Meaning in Much Ado About Nothing," Renaissance Forum, Vol. 2 No. 1 (Spring, 1997); <http://www.hull.ac.uk/renforum /v2no1/lucking.htm>.

40. Lucking refers to Will and Ariel Durant, The Age of Reason Begins (New York: Simon and Shuster, 1961) as an exponent of this view. Cf. Lucking.

41. Lucking.

42. Lucking. 
ture to say, into the nature of 'non-existence.' And, as far as I can see, it is the non-part of this word, or the no-part of nothing, which receives an early verbal index in the double negation nor 'twas not, a quote from a tale, as a preamble to the tale we are going to see and hear, a motto to what is entitled Much Ado About Nothing, where even the scene which can be rightfully called the most significant one with respect to dramatic deception, the scene in which Claudio witnesses Borachio's counterfeit wooing of Margaret, is hidden from the spectator's sight and is only reported. And it is reported by Borachio himself to Conrade (and overheard, in turn, by the two Watches), and Borachio, perhaps not insignificantly, refers to the whole incident as a "tale": "- I tell this tale vilely - I should first tell thee how the Prince, Claudio, and my master, planted and placed and possessed by my master Don John, saw afar off in the orchard this amiable encounter" (III.iii.143-147). Borachio even echoes the double negation before he starts his tale proper; to Conrade's question, "But art not thou thyself giddy with the fashion too, that thou hast shifted out of thy tale into telling me of the fashion?" he replies: "Not so, neither" (III.iii.136-139). As it has been observed several times, the play is, indeed, permeated with the replacement of so by show, connected, and connectable, with no (no-thing, non-existence). 43 This might be given a further - and here final - twist, which, this time, is less a split than a real connection.

Stanley Cavell, scrutinising, in The Claim of Reason, the question whether representation through language provides us with certainty about the existence of the object which we represent, at one point, among other things, observes:

Criteria [which must be present for something to be the case] are 'criteria for something's being so,' not in the sense that they tell us of a thing's existence, but of something like its identity, not of its being so, but of its

43. Now it seems to be a widely accepted fact that in Shakespeare's time nothing could also mean the female genitalia (as, for example, Hamlet, III.ii.101-109 testifies to it) as well as the insight that nothing could also be pronounced as noting: "The $o$ in nothing was long, and the th could be sounded as $t$ (as still in some regional or plebeian speech)” (Humphreys, p. 135). So when Balthazar apologises for his bad voice and says: "Note this before my notes; / There's not a note of mine that's worth the noting" and Don Pedro answers: "Why, these are the very crochets [musical quarter notes] that he speaks! / Note notes, forsooth, and nothing!" (II.iii.54-57), he might mean "pay attention to the musical notes and nothing else is important," or "to pay attention to musical notes is to note nothing worth noting," or "you note the notes and then you go on noting them: this is all what singing is about." (Cf. the note, provided by Stephen Greenblatt in The Norton Shakespeare, p. 1383.) 
being so. Criteria do not determine the certainty of statements, but the application of the concepts employed in statements. 44

According to Cavell's argument, based on Wittgenstein's Philosophical Investigations, it is not only in metaphorical or in poetic language (in fiction) that our certainty with respect to 'reality' is destabilised but in ordinary, everyday language as well. Approaching the problem from Ricoeur's side we might say that the 'not' is inhering in 'is' even when we say, in the most everyday sense: This is a chair. Yet Cavell's insight calls attention to so as well, so emphatically featuring in the original dictum: "It is not so, nor 'twas not so." Cavell calls our attention to the fact that we can never approach being (is, existence) 'directly'; what we have is, always already, an attitude, a way, a mode of relating to things, and to the question whether what we, in a given situation, are encountering is real or imaginary, the answer can only be "it depends": it depends not on the thing but on my attitude. Here is Cavell:

And I would want to say: The difference between real and imaginary, between existence and absence is not a criterial difference, not one of recognition. And so the answer to "Am I wrong?" is, It depends. It depends on whether the question I am asked is one of identification or of something else (something I waver between calling existence and reality). The problem, or something I am trying to make a problem, is: How do I know whether I am asked the one or the other? 45

Perhaps one way of answering Cavell's last question is to combine his insights quoted painfully sparingly here - with those of Ricoeur's on metaphor. Without trying to "solve" ancient riddles of aesthetics at one stroke, I offer the following contribution: reality, just like fiction, is always created in an attitude, in a mode of approaching what is before us; we are only given the so, never the is. Thus, whether what we, within the so, are encountering is 'real' or 'imaginary' will not depend on the amount of certainty we have with respect to the object approached; the object will always be in the mode of is and is not at the same time, it will always carry an affirmation of itself, and a denial of itself simultaneously: language, indeed, speaks with "double tongues." Art (the theatre, the play, the "funny words" in it) is not something opposed to 'reality' or 'removed' (twice or

44. Stanley Cavell, The Claim of Reason: Wittgenstein, Skepticism, Morality and Tragedy (Oxford: Oxford University Press, 1979), p. 45.

45. Cavell, p. 51. 
three times) from reality; from social contexts, through well-identifiable and socially acquired circumstances (signs, etc.) we will be able to tell whether we are in the theatre or not, we will sooner or later be able to tell whether we were dreaming or not, we understand that somebody is - ironically - disguising truth as a dream, we realise that a play is dramatising, in front of us, our relationship to the stage by representing precisely eavesdropping and "noting," etc. Yet all this is possible because we are somehow aware of the 'is not' in the 'is,' and it seems to me to be likely that this awareness, as part of our socialisation, grows in proportion to our participation in the imaginary, perhaps even more so when the imaginary - as in Much Ado, for example - emphatically calls our attention to itself as the imaginary, so that we may - in addition to 'naive' participation have a distance from it, so that we may also relate to it. This, I know, amounts to saying that the more we attend, for example, the theatre, the better grasp we will have on reality: the 'royal road' to reality is not to it directly but precisely through the imaginary. I at least believe this to be so, as I believe that within so, we construct both reality and the imaginary rather through 'it is not not so' than through either just 'is,' or just 'is not.' The difference in our respective attitudes while constructing reality and the imaginary might be that with respect to the imaginary we have a greater awareness of the ever-presence of not in is, or rather of the not not: we do not have a greater or lesser amount of certainty but a greater amount of awareness of, and a greater amount of intimacy with, the not not. But you might shake your head and say: "You heard the warning: Be bold, be bold, but not too bold, yet haven't you been too bold; is your much ado not another case of it is not so, nor it was not so: but indeed, God forbid it should be so?" 